\title{
NUMERICAL AND EXPERIMENTAL ANALYSIS OF A SHEAR CONNECTION MADE USING A TOP-HAT PROFILE
}

\author{
Paweł HELBRYCH ${ }^{1}$, Maciej MAJOR ${ }^{2}$, Jacek NAWROT ${ }^{3}$ \\ Czestochowa University of Technolgy, Częstochowa, Poland
}

\begin{abstract}
The paper proposed a numerical model of a shear connection between a reinforced concrete slab and a steel shape. The connection was made using a top-hat profile. A method for conducting experimental research on shear connections in the composite structures was presented. Geometric dimensions and material parameters of the analysed model of connection, on which the experimental research was conducted, were noted. The results of the conducted experimental research were compared to the results of the numerical analysis performed using ANSYS software. displecement curves were analysed for both cases and any correlation between experimental and numerical results was noted.
\end{abstract}

Keywords: composite structures, top-hat profile, ANSYS, numerical analysis, experimental analysis

\section{INTRODUCTION}

Increase in usage of steel-concrete composite floors in frame buildings causes perfecting of the existing and development of new constructional solutions [1]. One of the most effective constructions of this type is a floor in which a rolled steel section (most frequently I-section) is connected with a concrete slab made

\footnotetext{
${ }^{1}$ Corresponding author: Czestochowa University of Technology, Faculty of Civil Engineering, Akademicka st 3, 42-218 Częstochowa, Poland, +48343250963, phelbrych@bud.pcz.czest.pl

2 Corresponding author: Czestochowa University of Technology, Faculty of Civil Engineering, Akademicka st 3, 42-218 Częstochowa, Poland, +48343250965, mmajor@bud.pcz.czest.pl

${ }^{3}$ Corresponding author: Czestochowa University of Technology, Faculty of Civil Engineering, Akademicka st 3, 42-218 Częstochowa, Poland, +48343250965, jnawrot@bud.pcz.czest.pl
} 
on a special folded sheet [2]. The sheet fulfils the function of the lost shuttering during the assembly phase and, during the exploitation phase, acts as an external span reinforcement of the floor slab [4]. When using floors of this type, under a small tensile force, the most beneficial way of connecting the slab to the steel section is by using unwelded profiles, assembled mechanically using self-drilling screws or powder-actuated fasteners [3]. In this solution, the profiles and the sheet are installed to the steel beam simultaneously, thanks to which the assembly time shortens. The most commonly used profile of this kind is Hilti's X-HVB shear connector, attached to the beam using two powder-actuated fasteners [8]. Another solution using this method of connection is a continuous profile in the form of a folded sheet strip of a determined width [5]. This paper [6] proposes an alternative solution in the form of a top-hat profile (Fig. 1).

The top-hat profile, as opposed to other unwelded profiles, has greater bearing capacity (the bearing capacity of the top-hat profile is about twice that of the $\mathrm{X}$ HVB Hilti bearing capacity) and lower production cost. Limited experimental research was conducted which proved the usefulness of the top-hat profile in composite floors and the bearing capacity value for the assumed geometry of the profile was also determined.

Since experimental research generates significant costs, in the paper an attempt was made to develop a numerical model of a shear connection, made using a tophat profile. Thanks to the model, it will be possible to perform initial optimisation calculations for changing the geometric parameters of the profile (height, depth, and wall width) to choose the best solution, the usefulness of which will be proven in the experimental research.

\section{EXPERIMENTAL RESEARCH}

Experimental research on profiles for composite steel concrete beams is conducted on special models of shear connections [7]. These consist of part of a steel section (I-section) and two concrete slabs, connected via the examined profiles (Fig. 2).

The model is placed on a research station and under axial force, directed at the steel section. Thus, creation of a shearing force is triggered in the connection area, which the examined profiles are supposed to transfer. Simultaneously, for each stress increase, measures are taken of the vertical movements (displecements) which occur at the contact point between the slab and the steel element and on this basis, the bearing capacity and the ductility of the profile are determined. Profiles, whose deformability is large enough to prove the assumption of the perfectly yielding behaviour of a shear connection in the analysed construction, are considered ductile [7]. Profiles that do not meet this requirement are considered inductile. The ductility of the profiles influences 
their placement along the length of the beam: ductile profiles are placed at regular intervals, while inductile profiles are placed in accordance with longitudinal shearing force distribution.

Within the conducted experimental research, three models with a profile of 100 $\mathrm{mm}$ length and three models with a profile of $60 \mathrm{~mm}$ length were examined. The geometry of the examined profile is shown in figure 1.

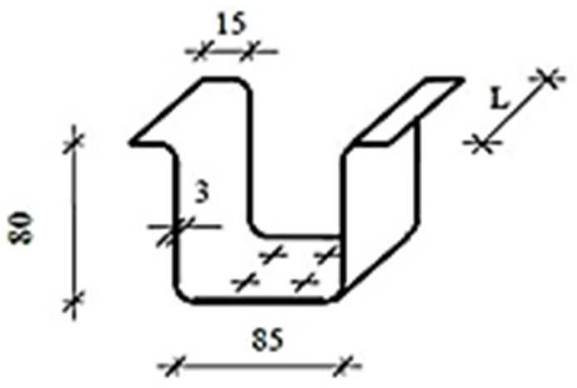

Fig. 1. A top-hat profile

The models were prepared for the following geometric and material data:

a) steel section:

- profile type: HEA 160;

- $\quad$ steel S235.

b) concrete slab:

- imensions: $105 \times 400 \times 550 \mathrm{~mm}$;

- concrete $\mathrm{C} 25 / 30$;

- $\quad$ reinforcement $\varnothing 10$, steel AII;

- trapezoidal sheet T55x188 width $0,75 \mathrm{~mm}$.

c) top-hat profile:

- geometry acc. to figure 1 ;

- steel S235;

- connection: 4 x Ø 4,5 ENP Hilti fasteners.

On the basis of the conducted research, capacity values of the profiles and displecements were determined and deformation forms of the examined connection were noted (Fig. 3).

\section{NUMERICAL MODEL OF THE EXAMINED CONNECTION}

Numerical calculations were made using ANSYS software which utilises a finite element method. All elements of the model were made as 10-node elements of the Solid type. The model was put under the stress of its own weight and shearing stress was distributed on the upper surface of the I-section HEA160. The support installed was a total displacement support (Fig. 4). 


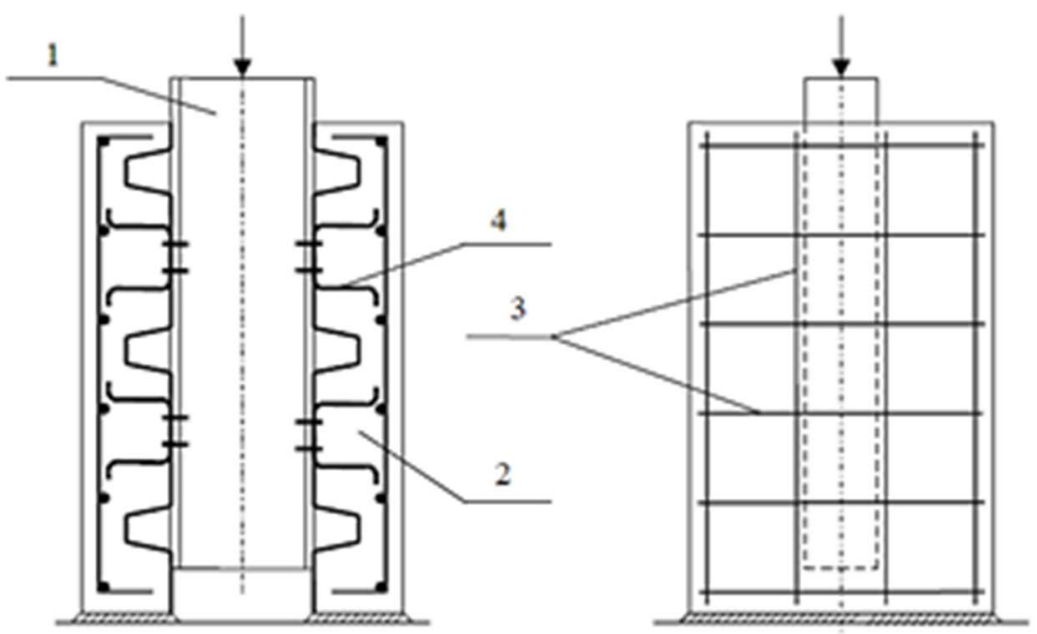

Fig. 2. Shear connection model: 1 - steel section, 2 - concrete slab on folded sheet, 3 - slab reinforcement, 4 - examined profile

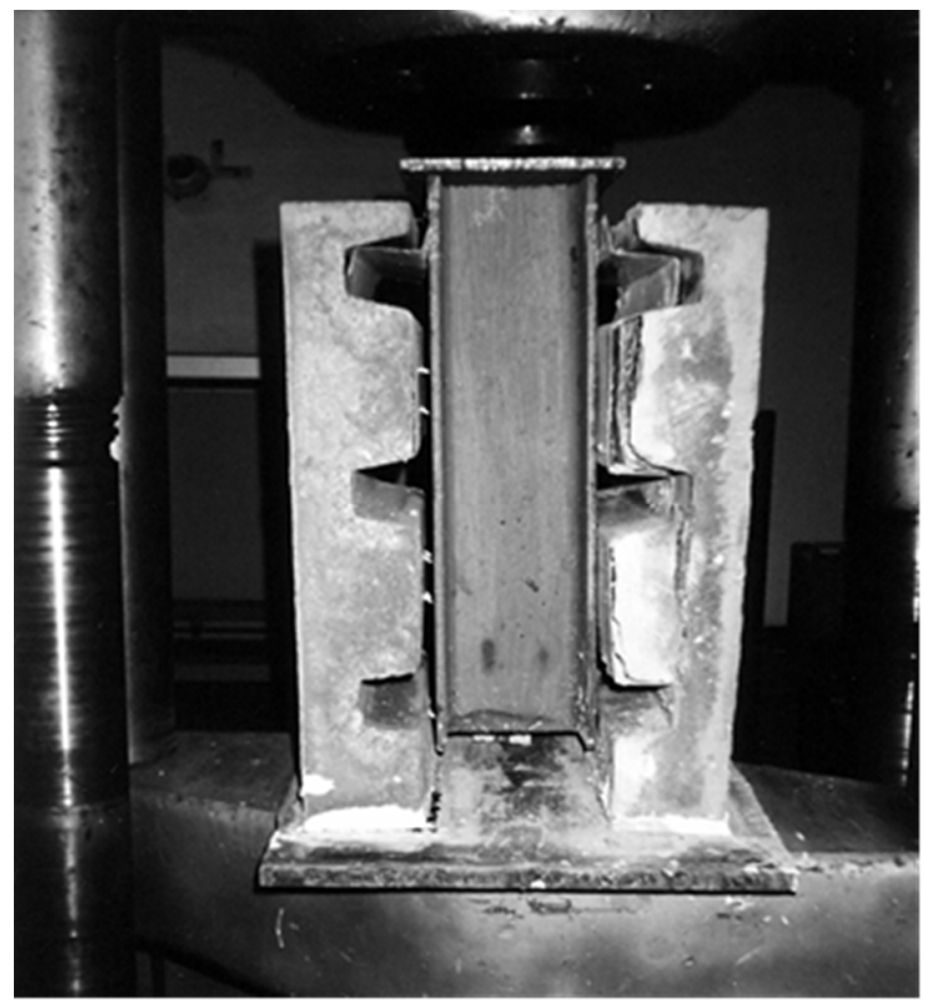

Fig. 3. Deformation form of the examined connection 


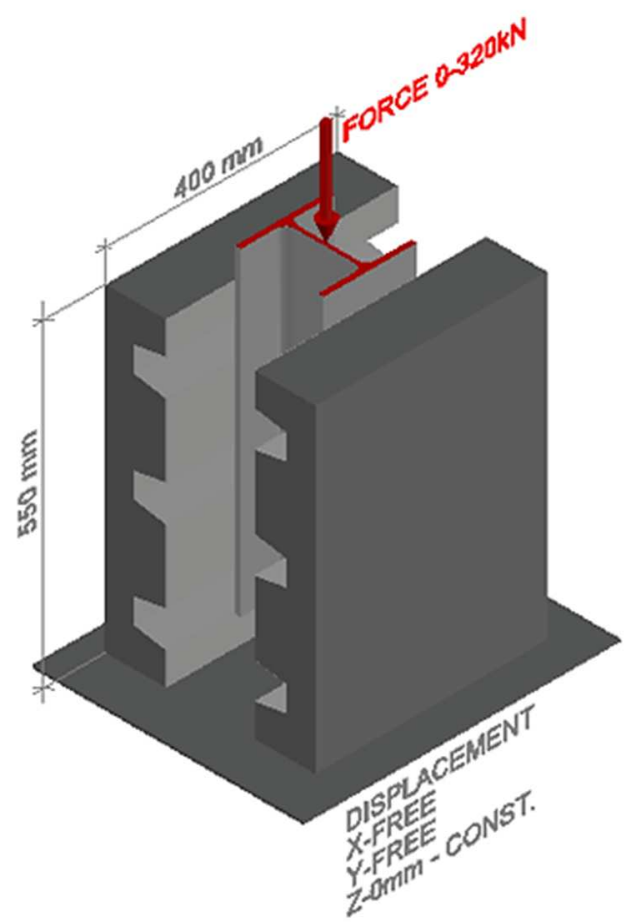

Fig. 4. Numerical model of the shear connection

Tetrahedrons method was used to generate projections of the model, using quadrilateral 10-node elements (Fig. 5).

a)

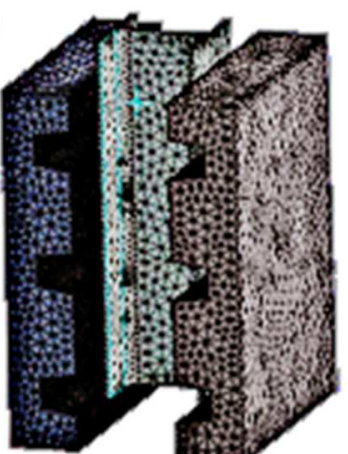

b)

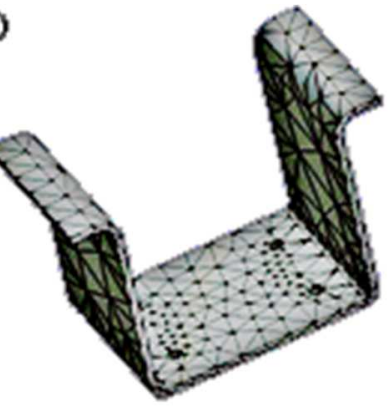

Fig. 5. Elements projection: a) examined model, b) top-hat profile

When modelling the contact points between the model parts, contact points declarations available in the ANSYS software were utilised.

For the HEA160 section, an elasto-plastic model of the material of the following parameters was assumed: 
- density $7850 \mathrm{~kg} / \mathrm{m}^{3}$;

- Poisson's ratio 0,3;

- Young's modulus $210 \mathrm{GPa}$;

- yield limit 292,25 MPa (determined experimentally);

- ultimate tensile strength 405,15 MPa (determined experimentally).

For the top-hat profile of $60 \mathrm{~mm}$ length, an elasto-plastic model of the material of the following parameters was assumed:

- density $7850 \mathrm{~kg} / \mathrm{m}^{3}$;

- Poisson's ratio 0,3;

- Young's modulus $210 \mathrm{GPa}$;

- yield limit 332,20 MPa (determined experimentally);

- ultimate tensile strength 415,25 MPa (determined experimentally).

For the trapezoidal sheet, an elasto-plastic model of the material of the following parameters was assumed:

- density $7850 \mathrm{~kg} / \mathrm{m}^{3}$;

- Poisson's ratio 0,3;

- Young's modulus $210 \mathrm{GPa}$;

- yield limit 277,25 MPa (determined experimentally);

- ultimate tensile strength $350,10 \mathrm{MPa}$ (determined experimentally).

For the shot-fired nails, an elasto-plastic model of the material of the following parameters was assumed:

- density $7850 \mathrm{~kg} / \mathrm{m}^{3}$;

- Poisson's ratio 0,3;

- Young's modulus $200 \mathrm{GPa}$;

- yield limit 350,0 MPa;

- ultimate tensile strength $650,0 \mathrm{MPa}$.

For the steel reinforcement bars, an elasto-plastic model of the material of the following parameters was assumed:

- density $7850 \mathrm{~kg} / \mathrm{m}^{3}$;

- Poisson's ratio 0,3;

- Young's modulus $205 \mathrm{GPa}$;

- yield limit 305,0 MPa;

- ultimate tensile strength $490 \mathrm{MPa}$.

For the concrete, an elasto-plastic model of the material of the following parameters was assumed:

- density $2500 \mathrm{~kg} / \mathrm{m}^{3}$;

- Poisson's ratio 0,2;

- Young's modulus $30 \mathrm{GPa}$;

- compression strength 16,08 MPa. 


\section{RESULTS ANALYSIS}

On the basis of the calculations made, it was determined that the greatest general deformation for the maximum shearing force equal to $320 \mathrm{kN}$ occurs in the sheet, on the edge of the composite slab, at the contact point of the concrete slab, and equals 15,46 mm (Fig. 6).

A disconnection between the sheet and the concrete slab was noted. The maximum deformation of powder-actuated fasteners connecting the profile to the HEA 160 section equalled 3,55 mm, and deformation of the top-hat profile equalled $4,41 \mathrm{~mm}$.

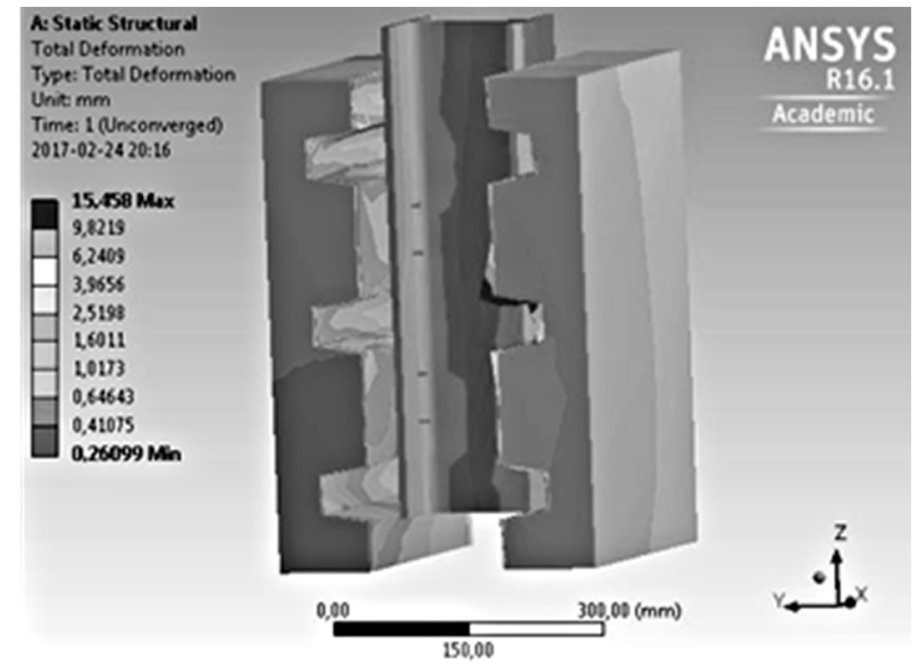

Fig. 6. General deformation of the analysed shear connection model

Since, during experimental research, deformation values of the sheet, the profile, and the fasteners were not measured, comparison between experimental research results and numerical analysis is not possible in this area. However, these occurrences were noted in the experimental research. The deformation form in the numerical model is the same as the deformation that occurred during the experimental research - deformation of the lower sheet folds and deformation of the fasteners connecting the profile (Fig. 7).

Vertical deformation (the displecement on the contact point between the HEA160 and the concrete slab) was determined in the function of the applied load, similarly as in the experimental research. Vertical deformation value (displecement) determined for the maximum shearing force equal to $320 \mathrm{kN}$ is $3,2 \mathrm{~mm}$. The numerical analysis results were compared to the experimental research results (Fig. 8). 

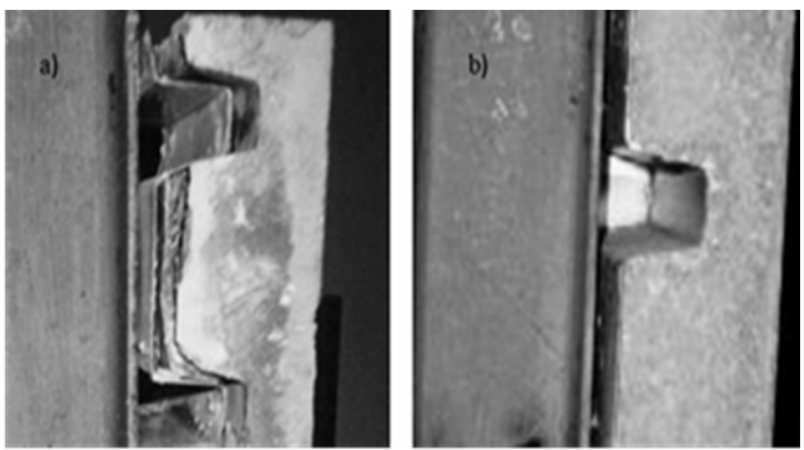

Fig. 7. Deformation of the analysed model: a) sheet fold deformation, b) fasteners connecting the profile deformation

Convergence was noted between experimental research displecement results and numerical analysis results, which proves a proper reflection of the behaviour of the shear connection in the analysed numerical model (Fig. 8).

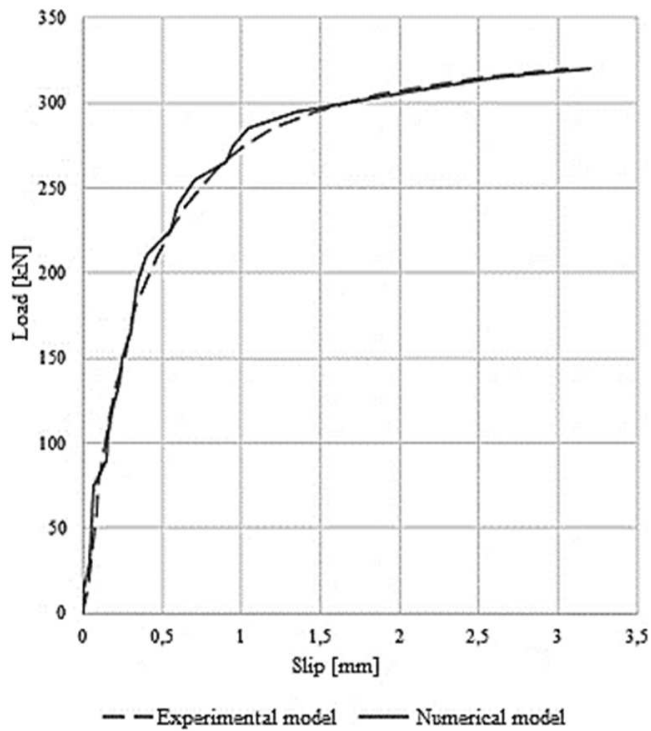

Fig. 8 The displecement between the concrete slab and HEA160 steel section: a) experimental model - averaged displecement curve for the three examined models, b) numerical model

Moreover, the concentration of shearing stress for maximum force equal to 320 $\mathrm{kN}$ was analysed. The focal point of the stress is located at the lower part of the top-hat profile, at the connection between the concrete slab and the HEA160 section (Fig. 9). 
The maximum shearing stress in the top-hat profile is placed on the contact point between the horizontal and vertical wall of the profile and equals 381,54 MPa. The profile undergoes plastic deformation but is not destroyed. This behaviour of the profile was proven in the experimental research - in none of the examined models was the material of the profile torn.

a)

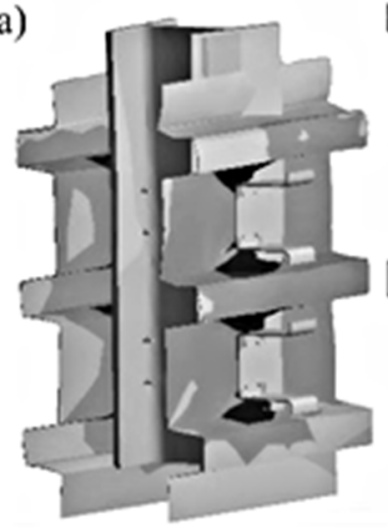

b)

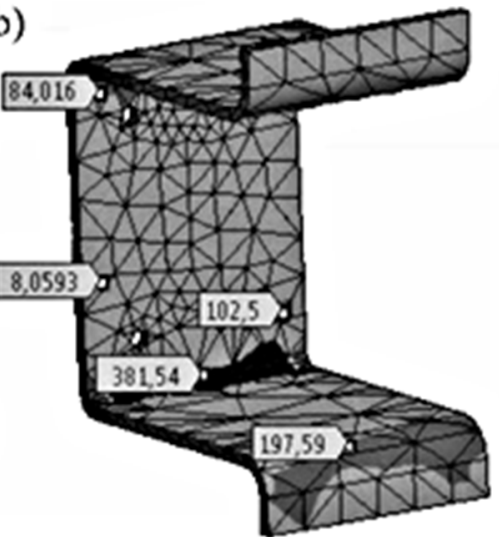

Fig. 9. Shearing stress in the numerical model: a) stress concentration point, b) shearing stress in the profile

\section{CONCLUSION}

The prepared numerical model properly recreates the behaviour of the shear connection made using a top-hat profile. Numerical analysis results determining the load/ displecement ratio, on the basis of which the profile capacity can be determined, are proven by the experimental research results - theoretical and actual displecement curves are the same (Fig. 8) and character of the deformations in the analysed model is similar to deformations noted during the experimental research. Achieved results confirm proper modelling of the analysed shear connection for the initial geometric assumptions and declared materials. The proposed numerical model may be used for initial verification of various geometrical variants of the profile in order to optimise its shape.

\section{REFERENCES}

1. Biliński, T. and Kmita, J. (2009). Dorobek nauki polskiej w zakresie konstrukcji zespolonych. Zielona Góra: Oficyna Wydawnicza Uniwersytetu Zielonogórskiego.

2. Bródka, J. and Kozłowski, A. (2003). Stalowe budynki szkieletowe. Rzeszów: Oficyna Wydawnicza Politechniki Rzeszowskiej. 
3. Kucharczuk, W. and Labocha, S. (2008). Konstrukcje zespolone stalowobetonowe budynków. Warsaw: Wydawnictwo Arkady.

4. Major, M. and Major, I. (2015). Konstrukcje zespolone $w$ budownictwie zrównoważonym. Budownictwo o zoptymalizowanym potencjale energetycznym, 16, pp. 51-56.

5. Moy, S., Jolly, C. and El Shihya, A. (1987). Unwelded Shear Connectors for Composite Beams, Composite Steel Structures. London-New York: E\&FN Spon, pp. 65-74.

6. Nawrot, J. and Kucharczuk, W. (2004). Badanie nośności nowych łączników do zespolonych stropów stalowo-betonowych. Inżynieria i Budownictwo, R.60 no 12, (2004) pp. 654-657.

7. (2008) PN-EN 1994-1-1 Eurocode 4: Projektowanie zespolonych konstrukcji stalowo-betonowych, Część 1-1: Reguty ogólne i reguty dla budynków. Brussels.

8. Thomas, D. and O'Leary, D. (1998). Composite beams with profiled-steel sheeting and non-welded shear connectors. Steel Construction Today, 2(4), pp. 117-121.

\section{ANALIZA NUMERYCZNA I DOŚWIADCZALNA POŁĄCZENIA ŚCINANEGO WYKONANEGO ZA POMOCĄ ŁĄCZNIKA KAPELUSZOWEGO}

\section{Streszczenie}

W pracy zaproponowano model numeryczny połączenia ścinanego płyty żelbetowej z kształtownikiem stalowym. Zespolenie wykonano przy użyciu łącznika kapeluszowego. Przedstawiono sposób prowadzenia badań doświadczalnych połączeń ścinanych w konstrukcjach zespolonych. Podano wymiary geometryczne oraz parametry materiałowe analizowanego modelu połączenia, dla którego wykonano badania eksperymentalne. Porównano wyniki przeprowadzonych badań doświadczalnych z wynikami analizy numerycznej wykonanej przy użyciu programu ANSYS. Przeanalizowano przebieg krzywych poślizgu dla obu przypadków wskazując korelację między wynikami doświadczalnymi i numerycznymi.

Keywords: konstrukcje zespolone, łącznik kapeluszowy, ANSYS, analiza numeryczna, analiza doświadczalna

Editor received the manuscript: 2.07.2017 